\title{
Modelled spatio-temporal variability of air temperature in an urban climate and its validation: a case study of Brno, Czech Republic
}

\author{
JAN GELETIČ ${ }^{1,2}$ Michal LEHNERT ${ }^{3}$ and Petr DOBROVOLNÝ ${ }^{1,2}$
}

\begin{abstract}
This study compares the results of air temperature model simulations with real temperature measurements in an urban environment. The non-hydrostatic micro-scale model MUKLIMO_3 is used to predict air temperature fields in Brno (Czech Republic). The development of the air temperature fields on three different days was modelled which characterising the radiation-driven weather conditions with high temperature that occurred during the summer of 2015. This analysis demonstrates that the model is able to reproduce the spatial distribution of the air temperature during the day. Statistical tests were applied to establish whether significant differences exist between the modelled and measured air temperatures. Verification of the model results against real temperature measurements was performed at five meteorological stations. The mean absolute differences between the simulated and measured daily mean temperatures were $0.7^{\circ} \mathrm{C}(4 \mathrm{July}), 0.6^{\circ} \mathrm{C}$ (18 July) and $0.5^{\circ} \mathrm{C}$ (28 August), respectively. This demonstrates that the model overestimated the real values, however, not all the differences were statistically significant. Moreover, there were no significant differences in the variability of the temperatures that were compared. This study also shows that the proper definition of Local Climate Zones and their parameters is critical for more precise model performance.
\end{abstract}

Keywords: MUKLIMO_3, urban air temperature, Local Climate Zones, GIS, spatial modelling

\section{Introduction}

The spatial and temporal variability of the air temperature in urban environments has been studied frequently in recent decades in connection with the formation of Urban Heat Islands (UHIs) (ARNFIELD, A.J. 2003). With the development of new data sources and new methodological approaches in recent years, research in urban climatology has shifted from identifying UHIs and estimates of UHI intensity to searching for the exact patterns of the spatio-temporal variability of UHIs and temperature fields in urban environments. Given the diversity of urban structure $\left(\mathrm{BECH}^{-}\right.$ TeL, B. and DaneKe, C. 2012; Lelovics, E. et al. 2014; LeHNERT, M. et al. 2015), qualities of relief (SAaroni, H. and ZIv, B. 2010; Boкwa, A. et al. 2015) and the variability of synoptic conditions (Gedzelman, S.D. et al. 2003; PrZYBYLAK, R. et al. 2015), it is a fairly complex and challenging task. Contemporary studies of the temperature fields of cities and their surroundings, therefore, impose high demands on the density and quality of the station network and the frequency and range of mobile measurements. At the same time, it appears that the current methods of remote sensing focusing on land surface temperature variability may not provide relevant information about air temperature (Voogt, J.A. and Оке, T.R. 2003). Recently, numerical modelling has come to represent another opportunity leading to more detailed and more accurate

\footnotetext{
${ }^{1}$ Department of Geography, Faculty of Science, Masaryk University Brno, Kotlářská 2, 61137 Brno, Czech Republic. E-mails: geletic.jan@gmail.com, dobro@sci.muni.cz

${ }^{2}$ Global Change Research Institute of the Czech Academy of Sciences, Bělidla 986/4a, 60300 Brno, Czech Republic.

${ }^{3}$ Department of Geography, Faculty of Science, Palacký University Olomouc. 17. Listopadu 12, 77146 Olomouc, Czech Republic. E-mail: michal.lehnert@gmail.com
} 
information about the spatio-temporal variability of urban air temperatures and UHI parameters.

Because of the progress in exploring the complexity of processes driving the climate system, models designed for application on scale of the city have gradually been developed. The first models demonstrated the differences in the energy balance between the city and its surroundings (e.g. Mills, G. 2009). The current state of the art numerical models make it possible to solve the thermodynamics of the atmosphere and complex relations between variables, such as the height of buildings and the structure of the buildings, materials used, height and the types of vegetation on the scale of the urban environment (SIEvers, U. AND ZDUNKOWSKI, W. 1985; Gross, G. 1989; Baklanov, A. et al. 2009). While numerical modelling offers very important information on urban temperature fields, another quite important task is the validation of the model outputs. Hollosi, B. et al. (2014) indicate that these results could not be validated as a result of the lack of observations.

The MUKLIMO_3 thermodynamic model developed by Deutscher Wetterdienst (2014) in collaboration with Zentralanstalt für Meteorologie und Geodynamik was used to analyse the main features of air temperature variability in Brno (Czech Republic). The primary aim of this contribution is to validate the MUKLIMO_3 outputs using air temperatures measured at several meteorological stations located in the city of Brno. The comparison is performed for several days that represent typical air temperature (more detail in section Meteorological data) conditions in Brno during the heat waves in the summer of 2015.

\section{Study area}

The study area is situated in the south-eastern part of the Czech Republic (Figure 1). Brno $(49.2 \mathrm{~N}, 16.5 \mathrm{E})$ is the second-largest city in the country (population 400,000, land registry area $230 \mathrm{~km}^{2}$ ) and is characterised by a basin position with complex terrain. Altitudes range from $190 \mathrm{~m}$ to $479 \mathrm{~m}$ a.s.l. with the higher elevations lying largely in the western and northern parts of the region. Lower and flatter terrain is typical of the southern and eastern parts of the study area. There is a water reservoir (area approx. $2.6 \mathrm{~km}^{2}$ ) located on the northwest border of the built-up part. The study area lies in one of the warmest and driest regions in the Czech Republic. The mean

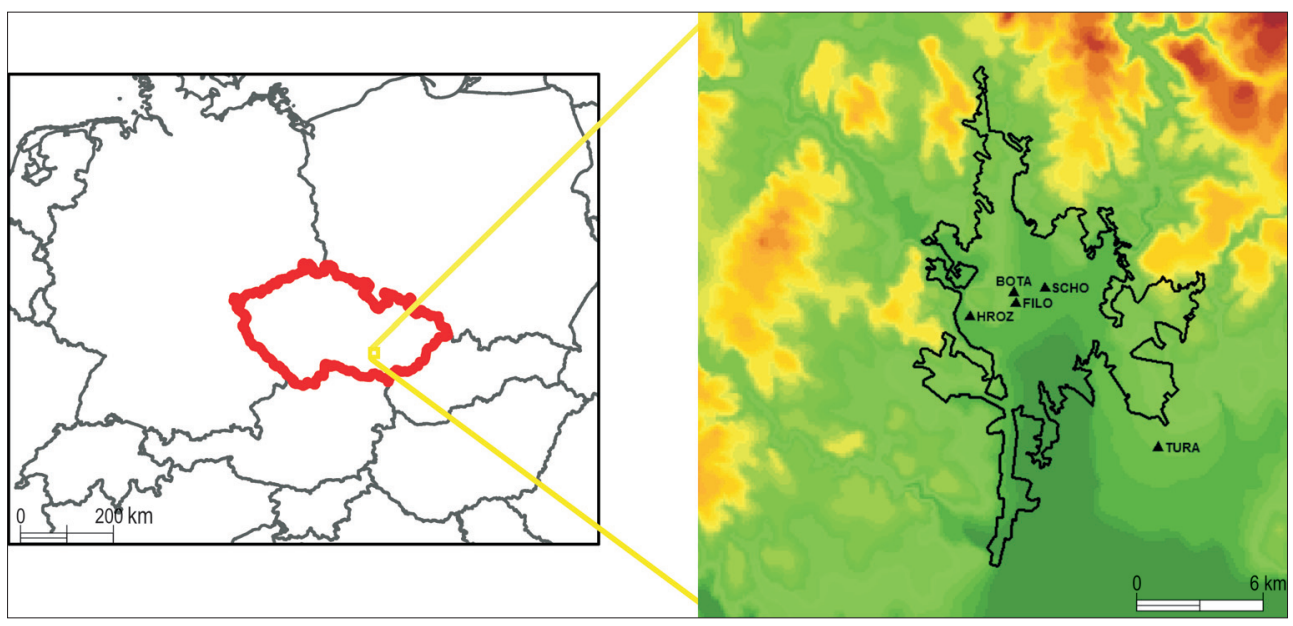

Fig. 1. Elevation in the study area of Brno, position of validation stations and boundary of compact city structure 
annual temperature stands at $9.4{ }^{\circ} \mathrm{C}$, while the mean annual precipitation is around $500 \mathrm{~mm}$ (1961-2000 reference period).

The highest density of built-up areas occurs in the historical city centre. These are largely residential ( $20 \%$ of the study area). There are several industrial zones and large shopping centres with high percentages of impervious surfaces (almost 14\% of the total area). Several large parks are located relatively close to the city centre. Further from the centre, individual land-cover categories form a mosaic of different surface types, such as blocks of flats, gardens, allotments and agricultural fields. Arable land and grasslands cover $34 \%$ of the study region and are situated mostly in the south, while forests take up $29 \%$ of the region and are to be found largely west and north of the built-up area, at higher elevations.

\section{Methods and data}

\section{MUKLIMO_3}

MUKLIMO_3 (3D Mikroskaliges Urbanes KLIma MOdel) is a non-hydrostatic microscale model with z-coordinates, which solves the Reynolds-averaged Navier-Stokes equations to simulate atmospheric flow fields in the presence of buildings (SIEvers, U. and Zdunkowski, W. 1985; Gross, G. 1989; Sievers, U. 1990, 1995). The thermo-dynamic version of the model includes prognostic equations for atmospheric temperature, relative humidity, wind speed and wind direction (Sievers, U. et al. 1983). The model uses high-resolution orography, land use distribution data and the vertical profile of the atmosphere (up to $1 \mathrm{~km}$ above ground level). Land use classes were defined on the basis of Local Climate Zones (see below).

For each land use class a set of parameters is defined which describes land use properties and urban structures: building fraction $\left(\gamma_{b}\right)$, mean building height $\left(h_{b}\right)$, wall area index $\left(w_{b}\right)$, fraction of pavement of the non-built area $(v)$, fraction of tree crown canopy $\left(\sigma_{t}\right)$ and fraction of low vegetation of the remaining surface $\left(\sigma_{c}\right)$, height of low vegetation $\left(h_{c}\right)$ (Table 1$)$, as well as leaf area index $\left(L A I_{c}\right)$ of the canopy layer, the mean height $\left(h_{t}\right)$ and leaf area index $\left(L A I_{t}\right)$ of the trees, with separate values for the tree trunk and the tree crown area. The model does not include cloud processes, precipitation, horizontal run-off or anthropogenic heat.

MUKLIMO_3 was used to generate the development of the air temperature field in the study area during three selected days. The model simulation for each day was represented with 23 temperature maps with a resolution of $100 \mathrm{~m}$; the time step between two successive modelled fields was 60 minutes. The corresponding modelled and measured temperatures for five localities (stations) were compared with several statistical tests.

Basic statistical tests for testing true difference ( $t$-test) and variance (f-test) were used. A null hypothesis for a two-sample paired $\mathrm{t}$-test is that the true difference in the means is equal to 0 . The critical value of the T-distribution is 1.717144. For a two-sample f-test a null hypothesis that the true ratio of the variances is equal to 1 was used. The critical value of the F-distribution is 2.04777 .

\section{Local Climate Zones (LCZ)}

The scheme of local climatic zones (LCZs) according to STEWART, I.D. and OKE, T.R. has become a standard for the description of the environment in the field of urban climate research. LCZs are defined as regions with a characteristic surface cover, structure and material and human activity that span hundreds of metres to several kilometres on a horizontal scale (STEWART, I.D. and OKE, T.R. 2012). Bechtel, B. and Daneke, C. (2012), furthermore Lelovics, E. et al. (2014) subsequently moved the LCZ concept toward a generally recognised regional typology. For this study an LCZ was delimited using a GISbased method presented by Geletič, J. and Lehnert, M. (2016). The method was based on measurable physical properties of the en- 
Table 1. Parameters for Local Climate Zones in the MUKLIMO_3 model*

\begin{tabular}{c|l|r|r|r|r|r|r|r|c}
\hline Local & \multicolumn{1}{|c|}{ Climate Zone } & $\gamma_{b} \%$ & $h_{b} \mathrm{~m}$ & $w_{b}$ & $v \%$ & $\sigma_{t} \%$ & $\sigma_{c} \%$ & $h_{t} \mathrm{~m}$ & $h_{c} \mathrm{~m}$ \\
\hline 1 & Compact high-rise & 0.60 & 25.00 & 6.67 & 1.00 & 0.00 & 0.90 & 0.00 & 0.10 \\
2 & Compact midrise & 0.45 & 16.50 & 3.42 & 0.70 & 0.00 & 0.90 & 0.00 & 0.10 \\
3 & Compact low-rise & 0.45 & 9.20 & 2.40 & 0.40 & 0.00 & 0.80 & 0.00 & 0.10 \\
4 & Open high-rise & 0.30 & 25.00 & 7.00 & 0.20 & 0.00 & 0.60 & 8.00 & 0.10 \\
5 & Open midrise & 0.30 & 18.60 & 4.40 & 0.45 & 0.00 & 0.80 & 4.00 & 0.10 \\
6 & Open low-rise & 0.30 & 6.50 & 2.10 & 0.40 & 0.00 & 0.70 & 0.00 & 0.10 \\
7 & Lightweight low-rise & 0.75 & 3.00 & 1.80 & 0.20 & 0.00 & 0.30 & 0.00 & 0.10 \\
8 & Large low-rise & 0.40 & 6.80 & 2.00 & 0.80 & 0.00 & 0.80 & 0.00 & 0.10 \\
9 & Sparsely built & 0.15 & 8.50 & 2.10 & 0.45 & 0.00 & 0.80 & 8.00 & 0.10 \\
10 & Heavy industry & 0.50 & 18.00 & 2.00 & 0.80 & 0.00 & 0.80 & 0.00 & 0.10 \\
$\mathrm{~A}$ & Dense trees & 0.00 & 0.00 & 0.00 & 0.00 & 0.80 & 0.90 & 21.00 & 0.50 \\
$\mathrm{~B}$ & Scattered trees & 0.00 & 0.00 & 0.00 & 0.00 & 0.40 & 0.90 & 14.00 & 0.50 \\
$\mathrm{C}$ & Bush, scrub & 0.00 & 0.00 & 0.00 & 0.00 & 0.40 & 0.90 & 2.00 & 0.50 \\
$\mathrm{D}$ & Low plants & 0.00 & 0.00 & 0.00 & 0.00 & 0.00 & 1.00 & 0.20 & 0.50 \\
$\mathrm{E}$ & Bare rock or paved & 0.00 & 0.00 & 0.00 & 0.95 & 0.00 & 0.01 & 0.00 & 0.30 \\
$\mathrm{~F}$ & Bare soil or sand & 0.00 & 0.00 & 0.00 & 0.00 & 0.00 & 0.01 & 0.00 & 0.30 \\
$\mathrm{G}$ & Water & 0.00 & 0.00 & 0.00 & -1.00 & 0.00 & 0.01 & 0.00 & 0.30 \\
\hline
\end{tabular}

*Parameters: building fraction $\left(\gamma_{b}\right)$, mean building height $\left(h_{b}\right)$, wall area index $\left(w_{b}\right)$, fraction of pavement $(v)$, fraction of tree crown canopy $\left(\sigma_{t}\right)$, fraction of low vegetation $\left(\sigma_{c}\right)$, tree height $\left(h_{t}\right)$ and height of the low vegetation $\left(h_{c}\right)$. The fractions $\gamma_{b}$ and $\sigma_{t}$ are relative to the total grid cell area $(1 \mathrm{ha})$. The fraction $v$ is relative to the area without buildings and trees and $\sigma_{c}$ is relative to the remaining surface.

vironment derived from typical values of the geometric and surface cover properties of a particular LCZ as defined by STEWART, I.D. and OKe, T.R. (2012).

The values of the physical properties of the environment were calculated for $100-\mathrm{m}$ pixels on the basis of the ZABAGED vector geo-database and photogrammetric data $(3 \mathrm{D}$ model of development). The pixels were subsequently classified using a clearly defined decision-making algorithm that had been tested in the Central European environment. Finally, a two-stage majority filter was applied to define the local climate zones in the Brno (Figure 2). (For more details see GelEtič, J. and LEHNERT, M. 2016.)

\section{Meteorological data}

As MUKLIMO_3 provides the best results for radiation-driven weather conditions that are characterised by an almost clear sky, minimum cloud cover and weak advection
(Hollosi, B. et al. 2014), three days in the high summer season of 2015 were used for model validation (4 July, 18 July and 28 August). The maximum daily temperatures exceeded 30 ${ }^{\circ} \mathrm{C}$ and each of these days was the third day of one of the heat waves which affected Brno in the summer season of 2015. A heat wave was defined as at least three consecutive days on which the air temperature reaches over $30{ }^{\circ} \mathrm{C}$ (Meteorologický slovník výkladový a terminologický 2016).

Data from five stations was used for the validation of the model outputs (Table 2, and see Figure 1). Four stations belong to the local meteorological monitoring network, which has been in operation since 2009. These stations represent the specific features of urban weather, because they are located in urban areas among buildings and near the city centre with heavy traffic. The fifth station is a professional station of the Czech HydroMeteorological Institute (CHMI), which is located at the airport in Brno-Turany (Dobrovolný, P. et al. 2012). 


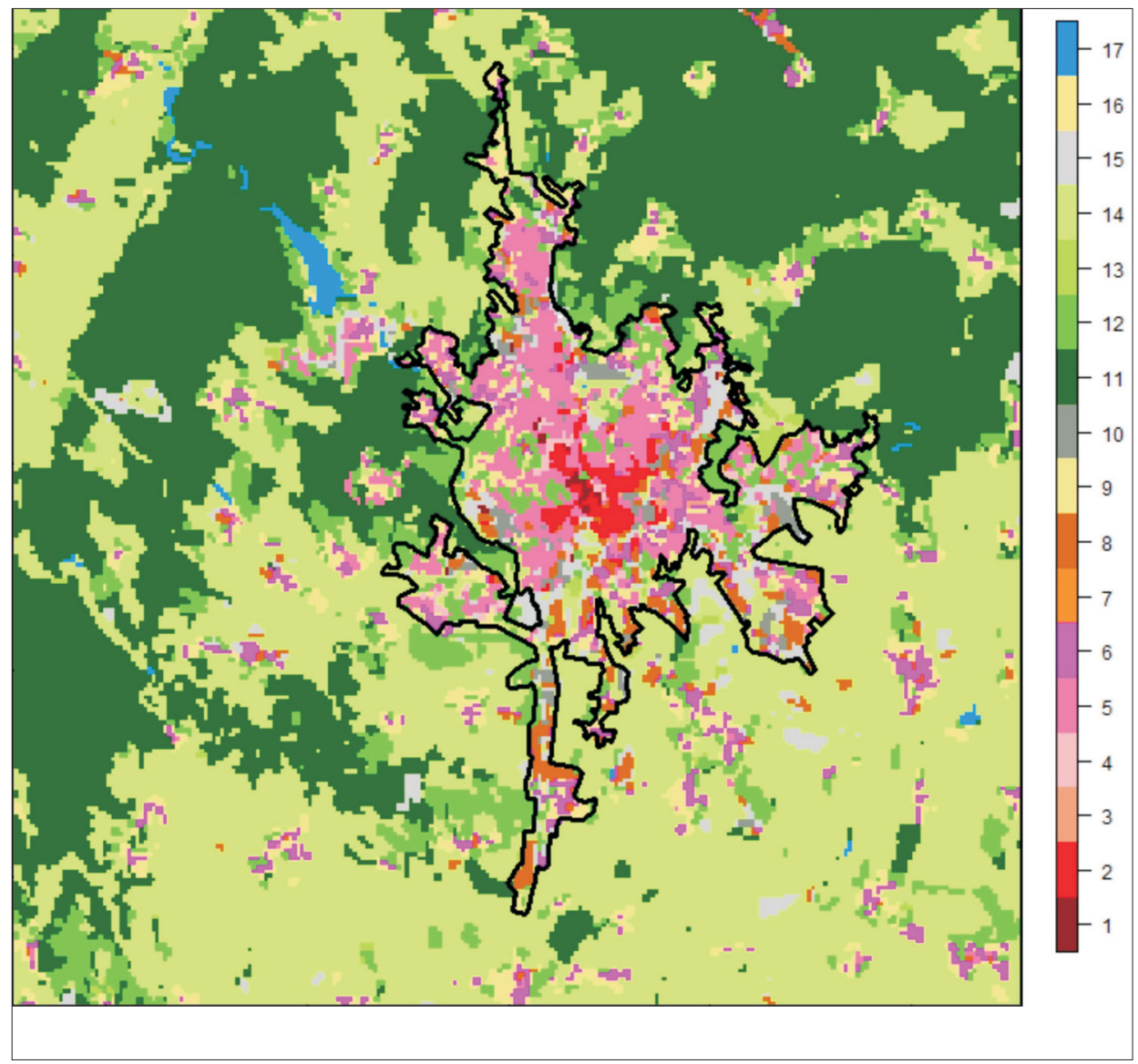

Fig. 2. Local climate zones in Brno and its surroundings (Geletič, J. and Lehnert, M. 2016). The values 11 to 17 correspond with the classes A to G (Coordinate system: S-JTSK / Krovak East North; EPSG: 5514).

Table 2. Validation stations and their characteristics*

\begin{tabular}{l|c|c|c|c|c|c|c}
\hline Station ID & Altitude, $\mathrm{m}$ & Longitude & Latitude & Exposure & LCZ & NDVI & DENS \\
\hline BOTA & 242 & 49.20417 & 16.59639 & $\mathrm{E}$ & 2 & 0.18 & 27 \\
FILO & 234 & 49.20028 & 16.59806 & $\mathrm{E}$ & 5 & 0.21 & 39 \\
HROZ & 214 & 49.19361 & 16.57222 & SW & 5 & 0.34 & 14 \\
SCHO & 225 & 49.20722 & 16.61389 & SW & B & 0.31 & 17 \\
TURA & 241 & 49.15306 & 16.68889 & S & D & 0.24 & 5 \\
\hline
\end{tabular}

*LCZ - LCZ class; NDVI - Normalised Difference Vegetation Index measuring amount of vegetation; DENS - density of buildings (\%) in $200 \mathrm{~m}$ radius around station.

All the station measurements were performed with a 10-minute frequency and hourly values of the air temperature were used for validation. The meteorological data (air temperature, relative humidity, wind speed and direction) necessary for the operation of the MUKLIMO_3 model were derived from the measurement of vertical profile of the atmosphere up a height of $1 \mathrm{~km}$ above surface at the Prostějov station located about $45 \mathrm{~km}$ north-east of Brno. In MUKLIMO_3 it is possible to use a minimum of one and a maximum of five layers for the same meteorological elements (Deutscher 
Wetterdienst 2014). We used three layers in our vertical profile, at 350, 660 and $980 \mathrm{~m}$. The height of the urban boundary layer can reach approximately $350 \mathrm{~m}$ above the ground (Menut, L. et al. 2015). Therefore it was supposed that the atmospheric conditions at these heights would probably be the same for Brno and for Prostějov. Meteorological data from the Brno-Turany station was used to represent the ground measurements of the study area. For each simulation different vertical profile was used.

The water temperature in the reservoir during the summer season was measured by the Regional Hygienic Station of the South Moravian Region in Brno.

\section{Results}

It follows from the model simulations that the places with the lowest air temperatures in the early morning hours before sunrise were located in the deep river valleys in the northern part of Brno (Figure 3, a). Generally, lower air temperatures are typical of LCZ A. After the sunrise the spatial distribution of the air temperature is predominantly influenced by altitude. At 7 a.m. (see Figure 3, a) the model forecasts $19^{\circ} \mathrm{C}$ for areas with a lower location (particularly the south-eastern part of the area of interest and valleys) and $16^{\circ} \mathrm{C}$ for areas with a higher location (particularly the northern and north-western parts of the area).
As the air gets warmer the model gradually generates areas with a higher proportion of LCZs 8, 10 or E that are warmer than their surroundings, including areas located outside the compact urban development. However, the distinct UHI is not formed until 1 p.m. according to the results of the model simulations. At 2 p.m. the UHI is formed over most of the city centre, including areas of LCZs 1 and 2. Higher temperatures were also simulated for smaller settlements with urban development. So-called hotspots were formed in areas with a higher proportion of LCZs 8, 10 or $\mathrm{E}$ with air temperatures above $31^{\circ} \mathrm{C}$. On the contrary, relatively cooler spots within the city correspond to larger areas of LCZ B, where air temperatures reach about $29^{\circ} \mathrm{C}$. The lowest temperatures are predicted for forested areas (LCZ A) at higher elevations located in the northern and north-western parts of the area of interest (around $26^{\circ} \mathrm{C}$ ). Thus the model simulates temperature differences of up to $5{ }^{\circ} \mathrm{C}$ between the warmest part of the city and the coolest forests at 2 p.m. (Figure 3, b).

The city centre and areas with a higher proportion of LCZs 8, 10 or E are expected to remain slightly warmer than their surroundings until the night hours. Higher temperatures occur around bodies of water (LCZ G). The model, however, forecasts a relatively low intensity of UHI during the evening and night hours. At 9 p.m. the warmest parts of

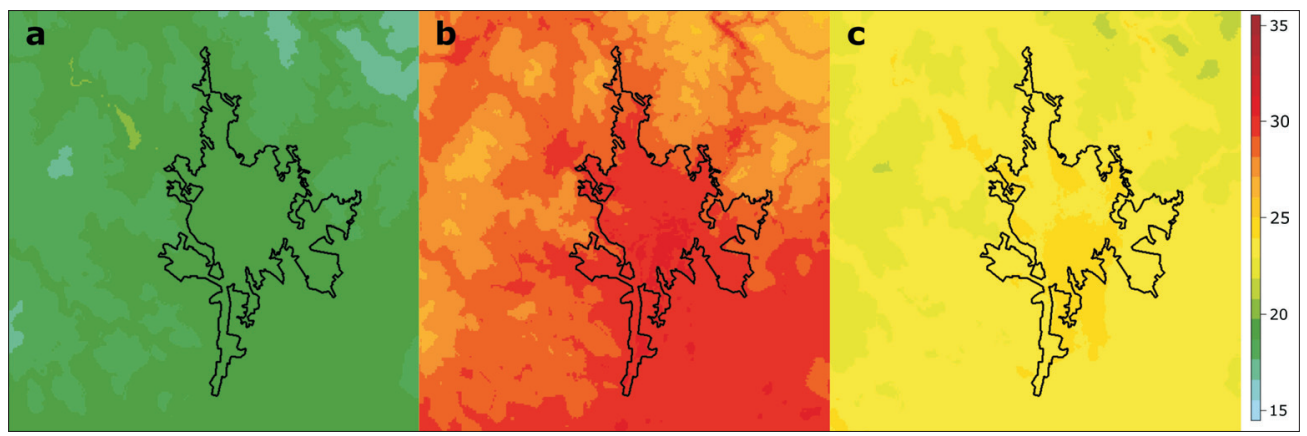

Fig. 3. Modelled spatio-temporal variability of the air temperature $\left({ }^{\circ} \mathrm{C}\right)$ in Brno on 28 August 2015 at 7.00 a.m. (a), at 2.00 p.m. (b) and at 9.00 p.m. (c) CET 
the city are only about $1{ }^{\circ} \mathrm{C}$ warmer than the agricultural landscape around the city (predominantly LCZ D) and up to $3{ }^{\circ} \mathrm{C}$ warmer than the forested areas (Figure 3, c).

In general, the MUKLIMO_3 simulations overestimate the real air temperatures on all three of the days that were analysed (Figure $4)$. The simulated mean daily temperatures were, on average, higher by $1.2^{\circ} \mathrm{C}$ (4 July), $0.6{ }^{\circ} \mathrm{C}$ (18 July), and $0.9^{\circ} \mathrm{C}(28$ August) than the measured temperatures. The temperatures were especially overestimated at the BOTA (LCZ 2) and HROZ (LCZ 5) stations. The minimum absolute difference occurred at the TURA station $\left(0.9^{\circ} \mathrm{C}\right)$ and maximum at the BOTA station $\left(1.2^{\circ} \mathrm{C}\right)$. Clearly higher model temperatures compared to measured ones occurred only on 4 July (in the starting phase of the model) and on 28 August (the model simulation assumes a sharp peak in the daily air temperature curve, whereas the real daily temperature curve showed lower maximum temperatures and simultaneously temperatures remained at relatively higher values for longer intervals). Minimum daily average difference occurred at the TURA station on 4 July $\left(0.8^{\circ} \mathrm{C}\right)$ and maximum at the FILO station on 4 July $\left(1.7^{\circ} \mathrm{C}\right)$.

A comparison of measured and simulated air temperatures for the three selected days demonstrates that the model successfully approximates the temperature variability through day and night at the locations of the individual stations (Figure 5). The smallest absolute difference between real and simulated air temperature was found for TURA. Station is located outside the compact urban structure at the international airport (LCZ D). The maximum mean difference is typical of the BOTA station, which is located within a compact city structure (LCZ 2) in a botanical garden inside the built-up area.

The differences between the modelled and measured air temperatures were further evaluated with several statistical tests (Figure 6). It allows evaluate the statistical significance of the differences that had been found between measurements and model outputs. The results of the t-test confirm that most model

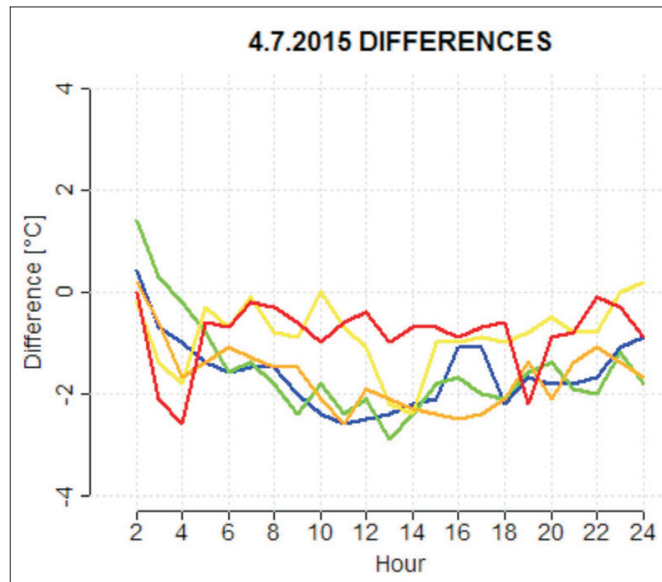

18.7.2015 DIFFERENCES

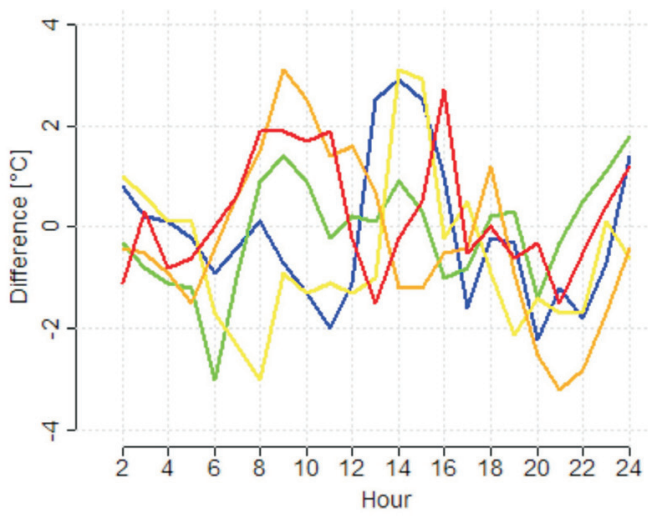

28.8.2015 DIFFERENCES

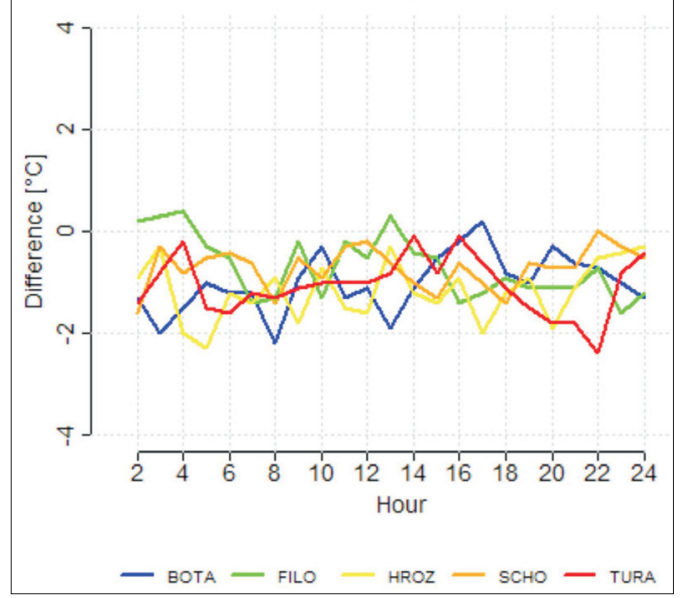

Fig. 4. Differences between real measurements and model outputs 


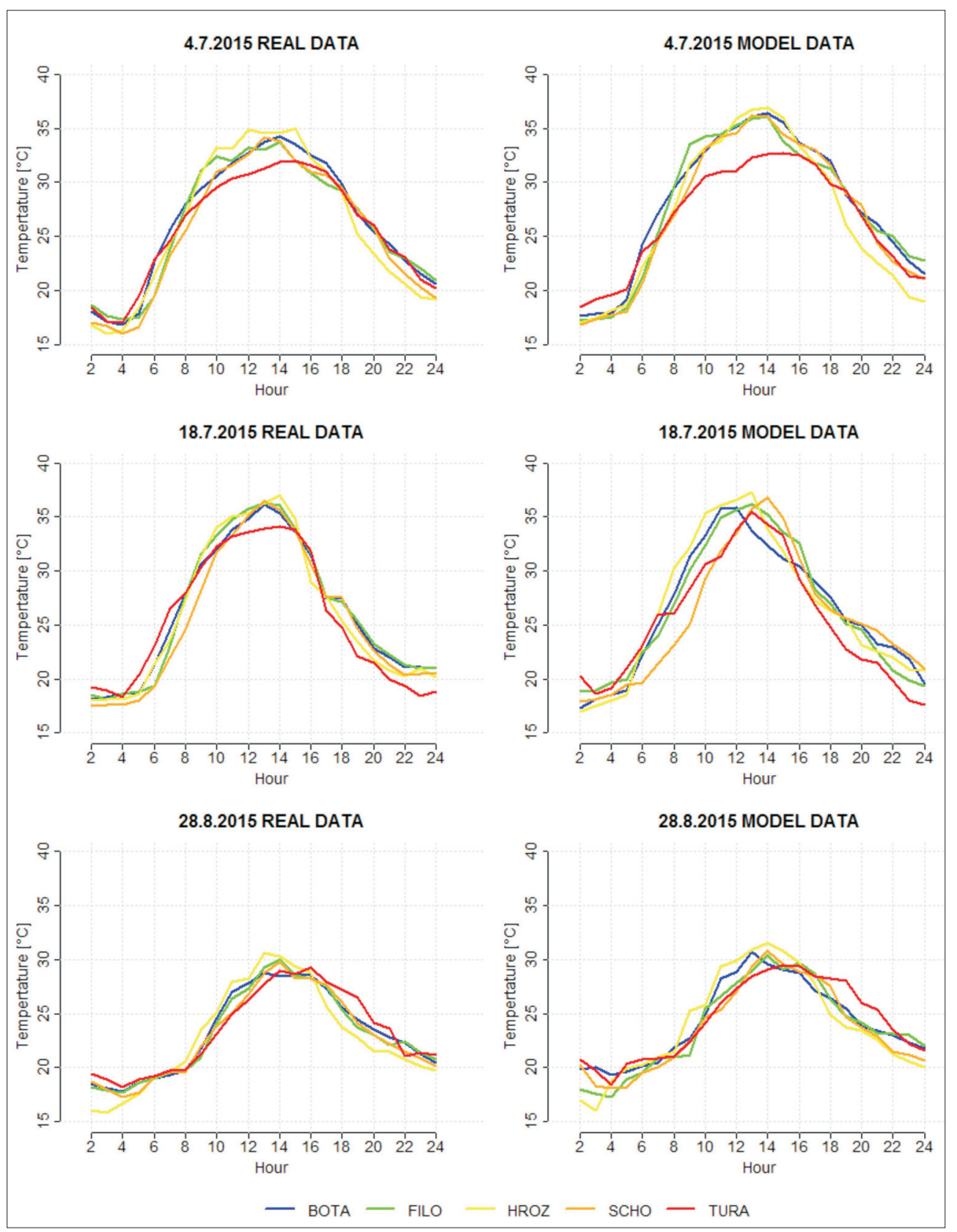

Fig. 5. Comparison between real measurements (left) and model outputs (right)

outputs are overestimated for all stations. While the mean daily modelled temperatures were significantly higher than the measured ones at all five stations on two of the days that were analysed (4 July, 28 August), there were no significant differences on 18 July $(p>$ 
0.05 for all stations except HROZ). Moreover, there were no significant differences in the temperature variability according to the Ftest $(p>>0.05)$ at any of the stations on all three days that were analysed.

\section{Discussion}

The comparison of the real station measurements and MUKLIMO_3 simulations in Brno and its surroundings shows that the model is able accurately to simulate the daily cycles of the air temperature at the five selected locations and to take into account some of the specific local features. The model corresponds best with the situation on 28 August 2015 (see Figure 4); this may be related to more stable atmospheric conditions very close to climatological autumn. Individual problems with the accuracy of the model simulation were primarily related to the starting phase of the modelling (esp. on 4 July 2015; see Figure 4). This problem may be related to the interaction of the 1D and 3D models. The 1D model starts before the 3D model and prepares the atmospheric conditions for the 3D model (Deutscher Wetterdienst 2014). In our case it starts 24 hours before the 3D model. This may be too far in advance. The correct settings of the Land Use Table parameter may also be responsible (see below).

At times when the surface displays a negative energy balance MUKLIMO_3 frequently assumes a sharp drop in the temperature earlier than the measurements (for example at the TURA station on 4 July) or steady decline rather than a sharp drop after sunset (at all stations on 18 July). This could largely be due to the complexity of the relief in Brno and its surroundings and the related local circulation systems.

The spatial patterns of the simulated temperature field correspond to the theoretical expectations in those periods when there is a positive energy balance.

The first hotspots were formed in the morning in LCZs 8, 10 and E, which indicates the beginning of UHI formation. In the early after- noon hours (1-3 p.m.) the central part of the Brno area was about $1-2{ }^{\circ} \mathrm{C}$ warmer compared to suburban areas and up to $4{ }^{\circ} \mathrm{C}$ warmer than the surrounding forests, according to the model outputs. The air temperature of a large part of the urban areas was not higher than in the areas where there was an agricultural landscape with a predominance of fields (LCZ D). This is in agreement with the findings of several other studies which indicated that the daily measurements of air temperatures in LCZ D may be higher than the temperatures measured in some types of compact built-up areas (e.g. LCZs 5 or 9; Houet, T. and Pigeon, G. 2011; LeHNERT, M. et al. 2015).

At night during the period of negative energy balance MUKLIMO_3 assumed a temperature that was just $1{ }^{\circ} \mathrm{C}$ higher in the centre of the city than in the suburbs and temperature that was $3{ }^{\circ} \mathrm{C}$ higher in the city centre than in the coldest forests. This may be compared to the results of mobile measurements in the Brno area (Dobrovolný, P. and Krahula, L. 2015). These authors claim that during the first half of the night in summer the city centre is almost $2{ }^{\circ} \mathrm{C}$ warmer compared to the suburbs and almost $5^{\circ} \mathrm{C}$ warmer than the surrounding rural areas. The actual comparison of the model results and station measurements does not refer to an underestimation of the intensity of the UHI effect. The differences in the average daily minimum temperatures between the stations that were analysed here, because of the absence of a reference station located in a cool area, smaller than measured Dobrovolný, P. et al. (2012). The surroundings of the city may actually be cooler than the model expects.

The analysis of the spatial patterns of the simulated temperature field shows that the MUKLIMO_3 model primarily reflects the effect of altitude. This is especially evident in the late afternoon and evening hours and during the night. The model predicts globally higher temperatures at lower altitudes. It can be considered as a simplification (ВокwA, A. et al. 2015). On the other hand, the model does not reflect the extent of the variability of building density (i.e. the amount and effect of accumu- 

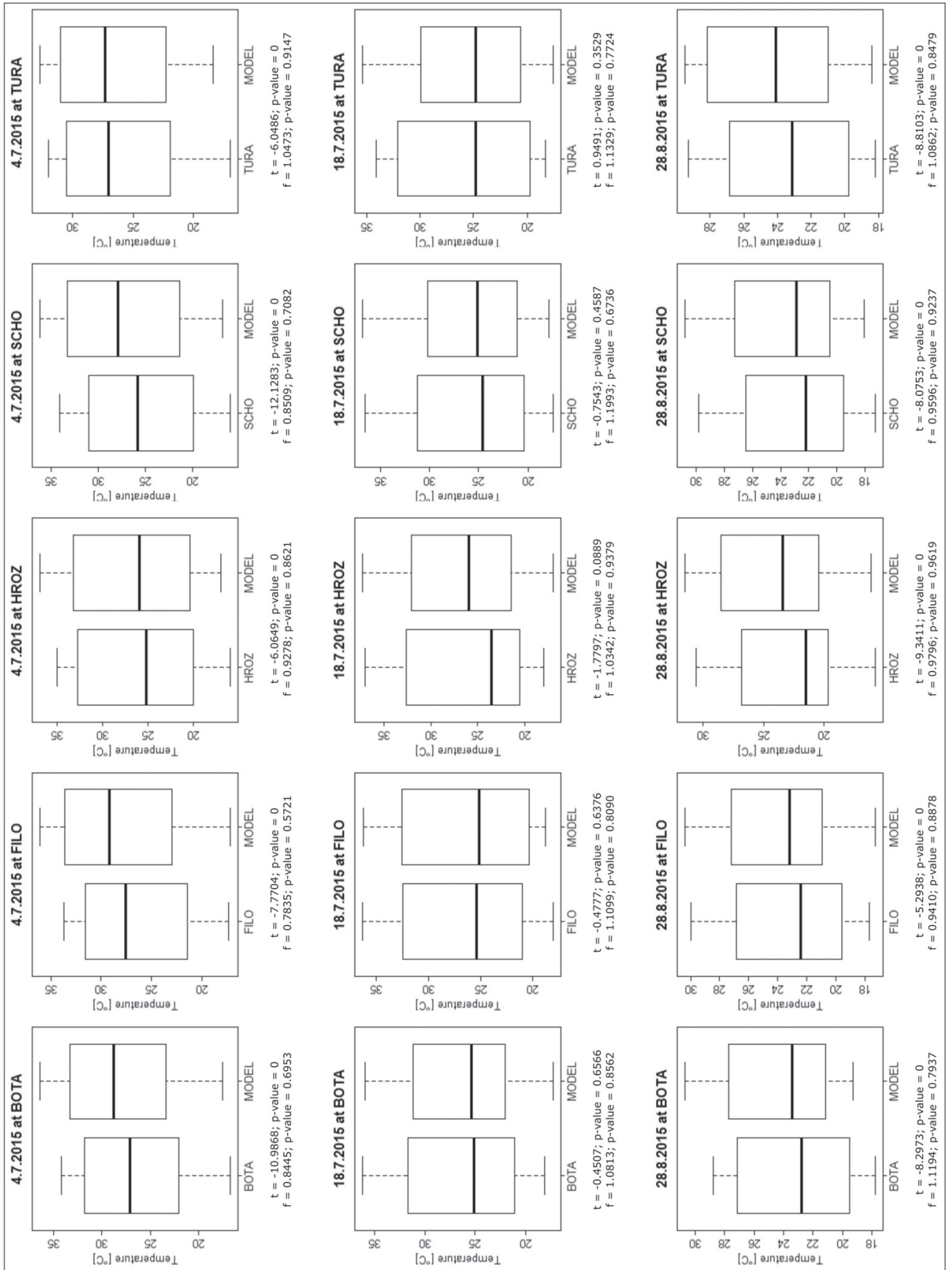

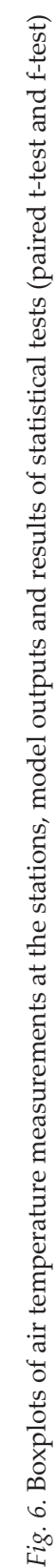


lated heat). It is anticipated that for more accurate simulation of the spatio-temporal temperature field it is necessary to focus attention on a Land Use Table. Moreover, it is possible that the concept of local climate zones (LCZ) is too general for modelling on a detailed level. It may cause incorrect settings of the thermal capacity of individual surfaces.

\section{Conclusion}

Using numerical models for the prediction of air temperature on a local scale represents progress in urban climatology. Although the MUKLIMO_3 simulations showed a number of uncertainties and customisation which must be improved (e.g. the classification of local climate zones seems to be too general as input for the Land Use Table), the model showed good performance in its approximation of the daily courses of air temperature in different urban environments. The degree of imprecision is highly dependent on the quality (e.g. representatives of meteorological measurement) and degree of generalisation (e.g. spatial resolution) of the input data. The model outputs may be used to study the development of the air temperature field in high temporal resolution (e.g. 60 minutes) but also for quantification of the effect of relief, land cover/use and weather conditions on local (urban) climate. The model is also useful to analyse UHIs. To reach a better performance the model must be validated in various cities with different landscape structures throughout the moderate climate zone. Therefore, it is necessary to continue to study the model settings and try to prepare optimal inputs for better results.

Acknowledgments: This contribution was prepared within the project "Urban climate in Central European cities and global climate change" of the International Visegrad Fund's Standard Grant No. 21410222 and the project "UrbanAdapt - Development of urban adaptation strategies using ecosystem-based approaches to adaptation", supported by grant EHPCZ02-OV-1-036-2015 from Iceland, Liechtenstein and Norway.

\section{REFERENCES}

Arnfield, A.J. 2003. Two decades of urban climate research: a review of turbulence, exchanges of energy and water, and the urban heat island. International Journal of Climatology 23. 1-26.

Baklanov, A., Grimmond, S., Alexander, A. and Athanassiadou, M. 2009. Meteorological and air quality models for urban areas. Heidelberg, Springer Berlin, $183 \mathrm{p}$.

Bechtel, B. and Daneke, C. 2012. Classification of local Climate Zones based on multiple Earth Observation Data. IEEE Journal of Selected Topics in Applied Earth Observations and Remote Sensing 5. (4): 1191-1202.

Bokwa, A., Hajto, M.J., Walawender, J.P. and Szymanowski, M. 2015. Influence of diversified relief on the urban heat island in the city of Kraków, Poland. Theoretical and Applied Climatology 122. (1-2): 365-382.

Deutscher Wetterdienst 2014. User's Guide MUKLIMO_3 Thermodynamik Version. Department of climate and environment consultancy. Offenbach am Main, $59 \mathrm{p}$.

DobrovolnÝ, P. and Krahula, L. 2015. The spatial variability of air temperature and nocturnal urban heat island intensity in the city of Brno, Czech Republic. Moravian Geographical Reports 23. (3): 8-16.

DobrovolnÝ, P., RezníčKová, L., Brázdil, R., Krahula, L., Zahradníček, P., Hradil, M., Doleželová, M., ŠÁleK, M., ŠTĚPÁNeK, P., RožNovsKÝ, J., VAlášEK, H., Kirchner, K. and KolejKa, J. 2012. Klima Brna. Víceúrovňová analýza městského klimatu. Brno, Masarykova univerzita. 200 p.

Gedzelman, S.D., Austin, S., Cermak, R., Stefano, N., Partridge, S., Quesenberry, S. and Robinson, D.A. 2003. Mesoscale aspects of the urban heat island around New York City. Theoretical and Applied Climatology 75. (1-2): 29-42.

Geletič, J. and Lehnert, M. 2016. Towards standardized mapping of local climate zones: the case of medium-sized Central European cities. Moravian Geographical Reports (in review).

Gross, G. 1989. Numerical simulation of the nocturnal flow systems in the Freiburg area for different topographies. Beiträge zur Physik der Atmosphäre 62. 57-72

Hollosi, B., Zuvela-Aloise, M. and Koch, R. 2014. Daily simulations of urban heat load in Vienna for 2011. EGU General Assembly Conference Abstracts 16. 6287.

Houet, T. and Pigeon, G. 2011. Mapping urban climate zones and quantifying climate behaviours - An application on Toulouse urban area (France). Environmental Pollution 159. (8-9): 2180-2192.

Lehnert, M., Geletič, J., Husák, J. and Vysoudil, M. 2015. Urban field classification by "local climate zones" in a medium-sized Central European city: the case of Olomouc (Czech Republic). Theoretical and Applied Climatology 122. (3): 531-541. 
Lelovics, E., Unger, J., Gál, T. and Gál, C.V. 2014. Design of an urban monitoring network based on Local Climate Zone mapping and temperature pattern modelling. Climate Research 60. 51-62.

Menut, L., Flamant, C. and Pelon, J. 1999. Urban boundary layer height determination from lidar measurements over the Paris area. Applied Optics 38. (6): 945-954.

Meteorologický slovník výkladový a terminologický 2016. ČMeS, eMS 1.3, version 2/2016, available at: http://slovnik.cmes.cz.

Mills, G. 2009. Luke Howard, Tim Oke and study of urban climates. $89^{\text {th }}$ American Meteorological Society Annual Meeting, Eighth Symposium on the Urban Environment 10-16.10. 2009.

Przybylak, R., Uscka-KowalkowsKa, J., AraźNY, A., Kejna, M., Kunz, M. and Maszewski, R. 2015. Spatial distribution of air temperature in Toruń (Central Poland) and its causes. Theoretical and Applied Climatology 10.1007/s00704-015-1644-2

SAARONI, H. and ZIV, B. 2010. Estimating the urban heat island contribution to urban and rural air temperature differences over complex terrain: application to an arid city. Journal of Applied Meteorology and Climatology 49. 2159-2166.
Sievers, U. 1990. Dreidimensionale Simulationen in Stadtgebieten. Umwelt-meteorologie, Schriftenreihe Band 15: Sitzung des Hauptausschusses II am 7. und 8. Juni in Lahnstein. Kommission Reinhaltung der Luft im VDI und DIN, Düsseldorf. 92-105.

Sievers, U. 1995. Verallgemeinerung der Stromfunktionsmethode auf drei Dimensionen. Meteorologische Zeitschrift 4. 3-15.

Sievers, U. and Zdunkowski, W. 1985. A numerical simulation scheme for the albedo of city street canyons. Boundary-Layer Meteorology 33. 245-257.

Sievers, U., Forkel, R. and Zdunkowski, W. 1983. Transport equations for heat and moisture in the soil and their application to boundary layer problems. Beiträge zur Physik der Atmosphäre 56. 58-83.

StewART, I.D. and OKE, T.R. 2012. Local Climate Zones for urban temperature studies. Bulletin of American Meteorological Society 93. (12): 1879-1900.

Voogt, J.A. and OKe, T.R. 2003. Thermal remote sensing of urban climates. Remote Sensing of Environment 86. (3): 370-384. 